\title{
Inhibitory Effects of Gynura procumbens Ethanolic Extract on Nitric Oxide Production and Inducible Nitric Oxide Synthase (iNOS) Protein Expression in Macrophages
}

(Kesan Perencatan Ekstrak Etanol Gynura procumbens terhadap Penghasilan Nitrik Oksida dan Ekspresi Protein Sintase Nitrik Oksida Teraruh (iNOS) di dalam Makrofaj)

TAN JiAH Ning, SyARATUl DALINA YusOFF, ZAKIAH Jubri, FHATAHEYA BUANG, TAN ZE SONG, AMEERAH BUDIONO, IBRAHIM JANTAN, ROZA DIANITA, ENDANG KUMOLOSASI, NORAZRINA AZMI \& NORSYAHIDA MOHD FAUZI*

\begin{abstract}
Nitric oxide (NO) overproduction by inducible nitric oxide synthase (iNOS) may be associated with acute and chronic inflammations. Macrophages as important cells in the innate immune system are able to be stimulated and can lead to iNOS activation and excessive NO production. Gynura procumbens is a medicinal plant traditionally used in treating various ailments including inflammation but the mechanism of anti-inflammatory activity of this plant is still elusive. This study was carried out to investigate the anti-inflammatory therapeutic effects of Gynura procumbens ethanolic extract on NO production and iNOS protein expression in RAW 264.7 macrophages stimulated with lipopolysaccharide (LPS). Cell viability of RAW 264.7 macrophages treated with Gynura procumbens ethanolic extract was determined by MTT assay. NO production was determined by Griess assay following Gynura procumbens ethanolic extract treatment alone or in combination with LPS stimulation. Protein expression of iNOS was determined by western blot. RAW 264.7 macrophages viability of more than 90\% was observed after 24 h treatment with Gynura procumbens ethanolic extract concentration range of $3.9 \mu \mathrm{g} / \mathrm{mL}$ to $500 \mu \mathrm{g} / \mathrm{mL}$. Significant inhibition of NO production level has been identified in LPS-stimulated RAW 264.7 cells pre-treated with $250 \mu \mathrm{g} / \mathrm{mL}$ Gynura procumbens ethanolic extract $(\mathrm{p}<0.05)$ while all selected concentrations of Gynura procumbens ethanolic extract showed no significant alteration of No production in the absence of LPS stimulation. Pre-treatment of $250 \mu \mathrm{g} / \mathrm{mL}$ Gynura procumbens ethanolic extract also demonstrated significant suppression of iNOS protein expression in LPS-stimulated RAW 264.7 cells $(\mathrm{p}<0.05)$. In conclusion, this study demonstrates that Gynura procumbens ethanolic extract exhibits anti-inflammatory potential through inhibition of NO production and $i N O S$ protein expression in LPS-stimulated macrophages, suggesting that this plant could be further researched for its beneficial use in inflammatory disorders.
\end{abstract}

Keywords: Gynura procumbens; inducible nitric oxide synthase; inflammation; lipopolysaccharide; macrophage; nitric oxide

\section{ABSTRAK}

Penghasilan nitrik oksida (NO) yang berlebihan oleh sintase nitrik oksida teraruh (iNOS) mungkin boleh dikaitkan dengan radang akut dan kronik. Makrofaj sebagai sel yang penting dalam sistem keimunan inat berupaya dirangsang dan menyebabkan aktivasi iNOS dan penghasilan NO yang berlebihan. Gynura procumbens ialah tumbuhan perubatan tempatan yang digunakan secara tradisi untuk merawat pelbagai jenis penyakit termasuk radang namun mekanisme aktiviti anti-radang oleh tumbuhan ini masih sukar difahami. Kajian ini dijalankan untuk mengkaji kesan terapeutik anti-radang oleh ekstrak etanol Gynura procumbens terhadap penghasilan NO dan ekspresi protein iNOS dalam makrofaj RAW 264.7 yang dirangsang oleh lipopolisakarida (LPS). Kebolehhidupan sel makrofaj RAW 264.7 oleh rawatan ekstrak etanol Gynura procumbens ditentukan dengan asai MTT. Reagen Griess digunakan untuk menentukan penghasilan NO diikuti rawatan ekstrak etanol Gynura procumbens atau dengan gabungan rangsangan LPS. Ekspresi protein iNOS dikaji dengan pemblotan western. Di bawah rawatan ekstrak etanol Gynura procumbens selama 24 jam menggunakan kepekatan $3.9 \mu \mathrm{g} / \mathrm{mL}$ hingga $500 \mu \mathrm{g} / \mathrm{mL}$, makrofaj RAW 264.7 menunjukkan kebolehhidupan sel lebih daripada 90\%. Perencatan paras penghasilan NO yang signifikan telah dikenal pasti dalam sel RAW 264.7 yang dirangsang oleh LPS bersama pra-rawatan $250 \mu \mathrm{g} / \mathrm{mL}$ ekstrak etanol Gynura procumbens $(\mathrm{p}<0.05)$ manakala semua kepekatan ekstrak etanol Gynura procumbens yang dipilih menunjukkan tiada perubahan yang signifikan dalam penghasilan NO tanpa perangsangan LPS. Pra-rawatan $250 \mu \mathrm{g} / \mathrm{mL}$ ekstrak etanol Gynura procumbens juga mendemonstrasikan perencatan ekspresi protein iNOS yang signifikan dalam sel RAW 264.7 yang dirangsang oleh LPS $(\mathrm{p}<0.05)$. Kesimpulannya, kajian ini menunjukkan bahawa ekstrak etanol Gynura procumbens mempamerkan potensi anti-radang melalui perencatan penghasilan NO dan ekspresi protein iNOS dalam makrofaj yang dirangsang oleh LPS, menunjukkan bahawa tumbuhan ini boleh dikaji secara lebih lanjut tentang kegunaannya yang bermanfaat dalam gangguan keradangan.

Kata kunci: Gynura procumbens; lipopolisakarida; makrofaj; nitrik oksida; radang; sintase nitrik oksida teraruh 


\section{INTRODUCTION}

Nitric oxide (NO) is a vital intracellular and intercellular signaling molecule involved in a wide range of physiological regulation and pathophysiological mechanisms. This simple diatomic molecule is produced from L-arginine by three nitric oxide synthase (NOS) enzymes: endothelial NOS (eNOS), neuronal NOS (nNOS), and inducible NOS (iNOS) (Aktan 2004; Soufli et al. 2016). The constitutively expressed eNOS and nNOS are responsible in the production of low physiological levels of NO (Hämäläinen et al. 2007). The No plays a role as biological mediator or host defense effector in neuronal system, vascular system and immune system. Yet, in contrast, the NO also acts as oxygen free radical and cytotoxic agent (Aktan 2004). Tissue damage is one of the consequences of NO overproduction where this pathological condition may be associated with acute and chronic inflammations (Joo et al. 2014). iNOS, which is absent in normal resting cells, is responsible for prolonged production of excessive NO by the induction of immunostimulatory cytokines, bacterial products or infection in different types of cells including macrophages (Korhonen et al. 2005).

Macrophages are pivotal cells in the innate immune system that possess the ability in the resolution of inflammatory responses (Tabas \& Bornfeldt 2016). This class of cells that are differentiated from circulating monocytes is the important immune player to engulf pathogens or damaged cells via phagocytosis and released of pro-inflammatory factors (Bobryshev et al. 2016). Other than the ability to promote inflammation, macrophages are also able to terminate the inflammatory response by deactivating or removing the mediators. Hence, the therapeutic intervention targeting the modulation of inflammatory mediators produced by macrophages is proposed as one of the possible route in controlling inflammatory associated diseases (Fujiwara \& Kobayashi 2005).

Cells of the myeloid lineage, which include macrophage, have been shown to be the primary cellular sensors for lipopolysaccharide (LPS) in mammalian immune system (Alexander \& Rietschel 2001). Activation of macrophages can be achieved by the binding of bacterial LPS to toll-like receptor 4 (TLR4), which in turn induces both MyD88-dependent and MyD88-independent pathways in the cells. Subsequently, mitogen-activated protein kinases (MAPKs) and nuclear factor kappa-B (NF$\mathrm{kB}$ ) signaling pathways are activated. The iNOS expression can be induced through the activation of multiple signal transduction pathways, including MAPKs (such as p38, ERK 1/2 or JNK), NF- $\mathrm{BB}, \mathrm{PI} 3$ kinase, and Janus tyrosine kinase (JAK)-signal transducers and activators of transcription (STATS). Accordingly, the binding of LPS is also able to stimulate macrophages to release cytokines and NO along with the activation of iNOS protein expression through multiple possible signaling pathways (Kim et al. 2007).

In recent years, researches on phytochemicals are getting more attention as more phytoconstituents are reported to demonstrate pharmacological benefits including modulation of inflammatory responses. Gynura procumbens (Lour.) Merr. (Family Compositae), also commonly called longevity spinach or 'Sambung Nyawa' in Malay language, is a decumbent perennial herb which is traditionally used for treatment of various ailments including inflammation, rashes, fever and hypertension (Kamaruzaman \& Noor 2017). The extract of Gynura procumbens exhibited inhibitory effect on the release of pro-inflammatory cytokine mediators such as IL-6, IL-8, MMP-1, MMP-9, TNF- $\alpha$ and IFN- $\gamma$ (Kim et al. 2011; Wong et al. 2015) whilst the anti-inflammatory cytokine IL-10 was significantly boosted upon administration of Gynura procumbens extract in vivo (Wong et al. 2015). Nonetheless, Gynura procumbens extract also showed potential in the medical usage as a topical antiinflammatory agent (Iskander et al. 2002).

Although the potential of Gynura procumbens extract in anti-inflammatory effect has been shown in vitro and in vivo, a more comprehensive investigation on antiinflammatory mechanism by Gynura procumbens extract is needed for the future development of therapeutic drug candidates treating illness related to inflammation. This study is the first to explore further the anti-inflammatory mechanism in Gynura procumbens ethanolic extract by focusing on the NO production and iNOS protein expression in activated macrophages as one of the current research aims to treat chronic inflammatory diseases is worked out by identifying substances that prevent excessive NO production (Taira et al. 2009).

\section{MATERIALS AND METHODS}

\section{MATERIALS}

Dimethyl sulfoxide (DMSO), Dulbecco's modified eagle medium (DMEM), fetal bovine serum (FBS), penicillin/streptomycin, N $\omega$-nitro-l-arginine methyl ester hydrochloride (L-NAME), lipopolysaccharide (LPS) from Salmonella enterica serotype typhimurium, [3-(4,5-dimethylthiazol- 2-yl)-2,5-diphenyltetrazolium bromide] (MTT) salts, phosphate buffer saline (PBS), Griess reagent, bovine serum albumin (BSA), radioimmunoprecipitation assay (RIPA) lysis buffer and protease inhibitor cocktail (PIC) were obtained from Sigma-Aldrich, USA. Sodium nitrite $\left(\mathrm{NaNO}_{2}\right)$ was obtained from Nacalai Tesque, Japan. Electrochemiluminescence (ECL) reagent was obtained from Thermo Scientific, USA. Bradford Protein Assay (BPA), Tris powder, glycine, sodium deococyl sulphate (SDS), Laemmli buffer, $\beta$-mercaptoethanol, Tris-HCL buffer pH8.8, Tris-HCL buffer pH6.8, ammonium persulphate (APS), acrylamide/bis solution 29:1 and N,N,N'-tetramethylethylenedeamine (TEMED) were purchased from Bio-Rad, USA. Monoclonal antibodies (iNOS, beta actin, HRP-linked secondary antibody) were obtained from Cell Signaling Technology, USA. PVDF membrane was obtained from Roche, Switzerland. 


\section{PLANT EXTRACTION}

The whole plant of Gynura procumbens was bought from Brightmark Sdn. Bhd, Semenyih, Malaysia and identified by botanist, School of Environmental and Natural Resource Sciences, Faculty of Science and Technology, Universiti Kebangsaan Malaysia. A specimen voucher of the plant was deposited in the herbarium of Universiti Kebangsaan Malaysia with a reference number UKMB40375. Extraction of Gynura procumbens was done by maceration with $80 \%$ ethanol by referring to Dianita et al. (2015). Dried plant weighing $250 \mathrm{~g}$ was soaked in $80 \%$ ethanol in $2 \mathrm{~L}$ conical flask for three days at room temperature and was occasionally stirred. After three days, filtration was done and the maceration was repeated for another two times. The solvent in the filtrates was evaporated using rotary evaporator to concentrate the extract. The ethanolic crude extract was kept in amber bottles and the solvent was allowed to dry at room temperature followed by complete drying by freeze dryer. The extract was dissolved in DMSO and kept at $4^{\circ} \mathrm{C}$ until further use. The final concentration of DMSO in the culture medium was controlled at $0.1 \%(\mathrm{v} / \mathrm{v})$.

\section{CELL CULTURE}

Murine macrophage cell line RAW 264.7 was obtained from ATCC and maintained in Dulbecco's Modified Eagle Medium (DMEM) supplemented with 10\% FBS, penicillin (100 units $/ \mathrm{mL})$ and streptomycin $(100 \mu \mathrm{g} / \mathrm{mL})$ at $37^{\circ} \mathrm{C}$ in $5 \% \mathrm{CO}_{2}$ atmosphere. Replacement of media was done every two to three days.

\section{MTT ASSAY}

To determine the RAW 264.7 cells viability under the treatment of Gynura procumbens extract, the cells were incubated with the extract at a wide range of concentration. The cell viability was evaluated by MTT assay which relied on the ability of metabolically active mitochondria in viable cells to cleave the MTT to form purple formazan. The RAW 264.7 cells were seeded in a 96-well plate at $5 \times 10^{4}$ cells/well. The plate was incubated for $24 \mathrm{~h}$ in $37^{\circ} \mathrm{C}, 5 \% \mathrm{CO}_{2}$ atmosphere. Then, the media was removed and replaced with Gynura procumbens extract $(3.9-500 \mu \mathrm{g} / \mathrm{mL})$ in serum free media. The vehicle control group are cells grown in serum free media containing $0.1 \%$ DMSO. After $24 \mathrm{~h}$ of treatment, tetrazolium salts $(5 \mathrm{mg} / \mathrm{mL}, 20 \mu \mathrm{L})$ was added into each well. The metabolically active cells will reduce the dye to form purple formazan. After $4 \mathrm{~h}$, the media containing MTT reagent was carefully discarded and $200 \mu \mathrm{L}$ of DMSO was added to dissolve the intracellular formazan product. After gentle shaking at room temperature for $20 \mathrm{~min}$, the absorbance was measured at $570 \mathrm{~nm}$. The percentage of cell viability was calculated as (Optical Density sample)/ (Optical Density of vehicle control) $\times 100 \%$.

\section{GRIESS ASSAY}

In the present study, Gynura procumbens extract was evaluated for the effect on NO production in non-stimulated and LPS-stimulated RAW264.7 cells. Griess assay was conducted to measure the amount of nitrite accumulation (a stable product of nitric oxide) as an indicator of NO production. RAW 264.7 cells were seeded in 96-well plate at $5 \times 10^{4}$ cells/well. After $23 \mathrm{~h}$ incubation $\left(\left(37^{\circ} \mathrm{C}, 5 \%\right.\right.$ $\mathrm{CO}_{2}$ atmosphere), the cells were pre-treated with Gynura procumbens extract at $3.9 \mu \mathrm{g} / \mathrm{mL}, 15.63 \mu \mathrm{g} / \mathrm{mL}, 62.5 \mu \mathrm{g} /$ $\mathrm{mL}$ and $250 \mu \mathrm{g} / \mathrm{mL}$ in serum free media. Control group only contained serum free media while $0.1 \%$ DMSO in serum free media served as the vehicle control. Positive control group was treated with $500 \mu \mathrm{M}$ L-NAME (nonselective NOS inhibitor). After $1 \mathrm{~h}$ of pre-treatment, the cells were induced with $1 \mu \mathrm{g} / \mathrm{mL}$ LPS and incubated for another $24 \mathrm{~h}$. Briefly, cell culture medium $(100 \mu \mathrm{L})$ from each well was transferred to new 96-well plate and mixed with $100 \mu \mathrm{L}$ of Griess reagent (1\% sulfanilamide and $0.1 \%$ naphthylethylenediamine dihydrochloride in $2.5 \%$ phosphoric acid). Subsequently, the mixture was incubated at room temperature for $10 \mathrm{~min}$ and the absorbance at 540 $\mathrm{nm}$ was measured in a microplate reader. Fresh culture medium was used as a blank in every experiment. The quantity of nitrite was determined from a sodium nitrite $\left(\mathrm{NaNO}_{2}\right)$ standard curve.

\section{WESTERN BLOT}

RAW 264.7 cells were seeded in 12-well plate at $5 \times 10^{5}$ cells/well. $24 \mathrm{~h}$ after cell seeding, the complete media was replaced by serum free media for cell starvation and incubated overnight to achieve cell quiescent and synchronization of the cell cycles. The cells were pretreated with Gynura procumbens extract $(3.9 \mu \mathrm{g} / \mathrm{mL}, 15.63$ $\mu \mathrm{g} / \mathrm{mL}, 62.5 \mu \mathrm{g} / \mathrm{mL}$ and $250 \mu \mathrm{g} / \mathrm{mL}$ ) and after $1 \mathrm{~h}$ the cells were induced with $1 \mu \mathrm{g} / \mathrm{mL}$ LPS. Following $8 \mathrm{~h}$ incubation, RAW 264.7 cells were washed with cold PBS twice and were scraped off from the well of cell culture plate. Cells were centrifuged to collect the cell pellet then resuspended in cell lysis buffer containing protease inhibitor cocktail. By using Bradford assay the protein concentrations of each sample were determined and normalized to equivalent protein concentration. Loading samples were prepared by adding Laemmli buffer and denatured for $5 \mathrm{~min}$ at $95^{\circ} \mathrm{C}$. After loading the samples in the well of acrylamide gel, proteins were separated by running SDS-PAGE. Separated proteins were transferred onto PVDF membrane, nonspecific sites were blocked by incubation in 5\% BSA solution for $1 \mathrm{~h}$. Immunodetection was performed overnight at $4^{\circ} \mathrm{C}$ using primary antibodies against iNOS (monoclonal, 1:1000) or $\beta$-actin (monoclonal, 1:5000) as loading reference, followed by HRP-linked secondary antibodies (anti-rabbit IgG: 1:1000) for $1 \mathrm{~h}$. Signal detection was done by chemiluminescence using the gel documentation camera. 


\section{STATISTICAL ANALYSIS}

All data were expressed as mean \pm SEM (standard error of mean). Statistical analysis was performed by using SPSS Version 22.0. The data were analyzed using analysis of variance (ANOVA) followed by Tukey's test. A value of $p<0.05$ was considered as significant.

\section{RESULTS AND DISCUSSION}

\section{EFFECT OF Gynura procumbens EXTRACT ON} RAW 264.7 CELL VIABILITY

Under the treatment of Gynura procumbens extract for 24 $\mathrm{h}$, no significant cytotoxicity was reported as compared to $0.1 \%$ DMSO vehicle control group. Generally, cell viability of RAW 264.7 was more than $90 \%$ of vehicle control (105 $\pm 4.42 \%, 102 \pm 0.65 \%, 100 \pm 0.80 \%, 100 \pm 0.65 \%, 97 \pm$ $0.73 \%, 99 \pm 1.38 \%, 98 \pm 1.30 \%$ and $94 \pm 2.95 \%)$ in the presence of $3.9,7.8,15.63,31.25,62.5,125,250$ and 500 $\mu \mathrm{g} / \mathrm{mL}$ of Gynura procumbens extract, respectively (Figure 1). Hence, all the tested Gynura procumbens extract concentrations were safe for the treatment on RAW 264.7 macrophages. With this result, Gynura procumbens extract concentrations of $3.9 \mu \mathrm{g} / \mathrm{mL}, 15.63 \mu \mathrm{g} / \mathrm{mL}, 62.5 \mu \mathrm{g} / \mathrm{mL}$ and $250 \mu \mathrm{g} / \mathrm{mL}$ were selected for subsequent experiments.

\section{EFFECT OF Gynura procumbens EXTRACT ON NO PRODUCTION LEVEL IN RAW 264.7 CELLS}

As shown in Figure 2(A), the presence of $0.1 \%$ DMSO in vehicle control had no effect on the NO production level as compared to the control group with only serumfree media. Under all selected treatment concentrations, Gynura procumbens extract show no significant effects on the nitric oxide production level in non-stimulated RAW 264.7 cells.

LPS endotoxin originated from the cell wall of gramnegative bacteria is able to activate macrophages and stimulate the production of pro-inflammatory cytokines (Joo et al. 2014; Nicholas et al. 2007) as well as the generation of pro-inflammatory mediator of NO by iNOS (Shi et al. 2014) in inflammation and host defense. Referring to Figure 2(B), the NO production level in RAW 264.7 cells significantly increased $(p<0.001)$ by the activation of LPS as nitrite accumulation was recorded at $6.55 \pm 0.37 \mu \mathrm{M}$. The treatment group with $500 \mu \mathrm{M}$ $\mathrm{N} \omega$-nitro-l-arginine methyl ester hydrochloride (L-NAME) as positive control elucidated significant inhibition $(p<0.001)$ in NO production induced by LPS. Accordingly, L-NAME as one of the L-arginine analogues, had been identified as non-selective NOS inhibitor (Kopincová et al. 2012; Łuszczki et al. 2011).

Pre-treatment of Gynura procumbens extract for 1 $\mathrm{h}$ prior to LPS activation had shown inhibitory effect on NO production in a dose-dependent manner. As shown in Figure 2(B), the nitrite concentration in the LPS activated groups treated with increasing concentrations of Gynura procumbens extract were $5.65 \pm 1.52 \mu \mathrm{M}, 5.04 \pm 0.95$ $\mu \mathrm{M}, 3.78 \pm 0.37 \mu \mathrm{M}$ and $2.06 \pm 0.34 \mu \mathrm{M}$. The inhibitory effect of NO production in LPS-stimulated RAW 264.7 was significant $(p<0.05)$ in cells pre-treated with $250 \mu \mathrm{g} / \mathrm{mL}$ Gynura procumbens extract. This significant inhibitory effect was comparable to the positive control group of $500 \mu \mathrm{M}$ L-NAME, which reduce the LPS-stimulated nitrite accumulation to $2.02 \pm 0.26 \mu \mathrm{M}$.

Gynura procumbens have been identified as a source of phytochemical compounds such as flavonoids, alkaloids, volatile oils, stigmasterol, chlorophylls and carotenoids. The flavonoids that have been reported in Gynura procumbens are quercetin, kaempferol-3O-rutinoside and astragalin (Akowuah et al. 2002; Kaewseejan et al. 2012; Mustafizur Rahman \& Al Asad 2013; Rosidah et al. 2008; Sunarwidhi et al. 2014). Certain flavonoids possess the ability to suppress NO production in LPS-activated RAW 264.7 cells in which the reduction of iNOS enzyme expression might contribute to this inhibitory effect. Specifically, astragalin is a potent inhibitor of NO production via the downregulation of iNOS expression (Kim \& Kim 2011; Li et al. 2014; Ma

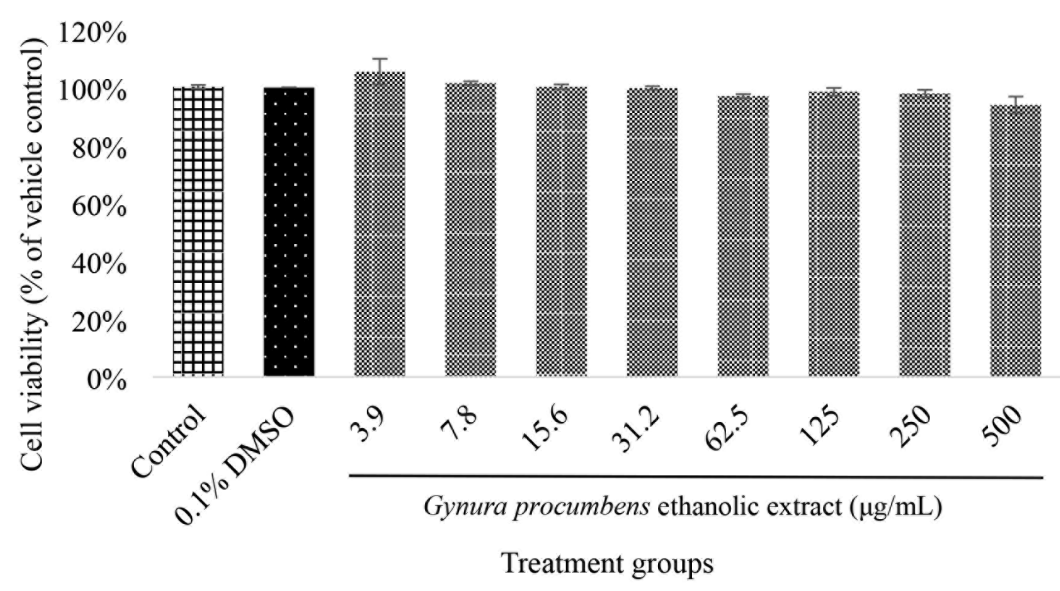

FIGURE 1. No cytotoxic effect of Gynura procumbens extract on RAW 264.7 cells when compared to vehicle control containing $0.1 \%$ DMSO. Values are mean \pm SEM for three independent experiments $(n=3)$ 


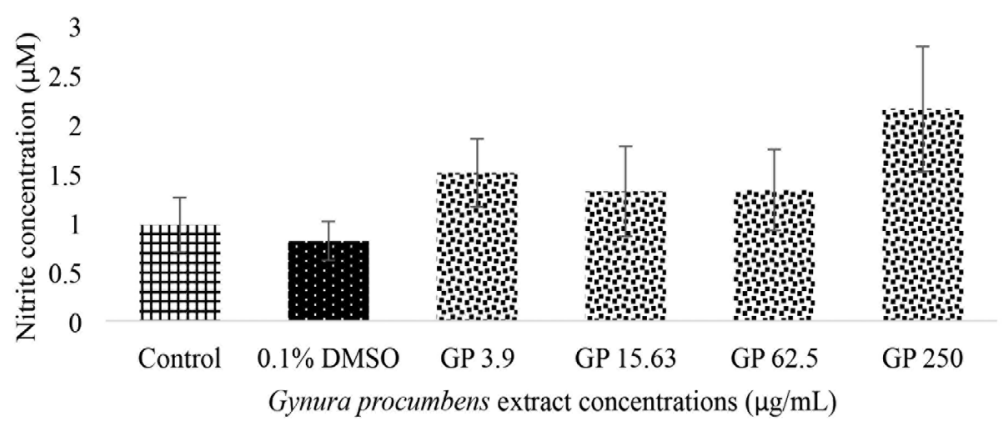

(A)

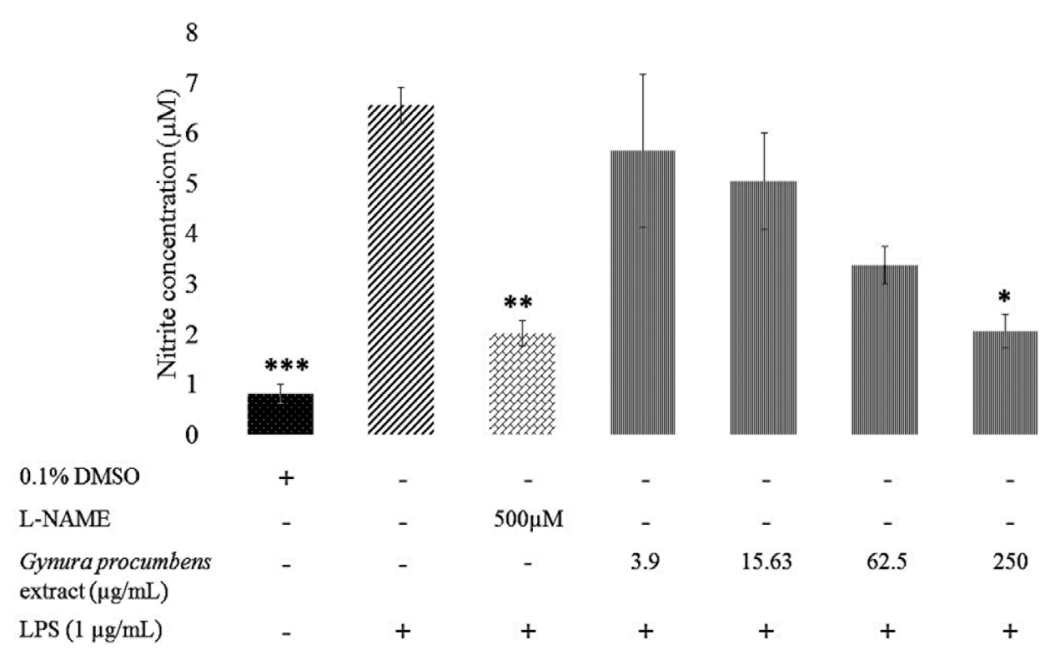

(B)

FIGURE 2. Effects of Gynura procumbens extract on nitric oxide (NO) production by (A) non-stimulated or (B) LPS-stimulated RAW 264.7 cells. Values are mean \pm SEM of three independent experiments $(n=3)$. Significant difference compared to LPS-stimulated group $*(p<0.05) ; * *(p<0.001) ; * * *(p<0.0001)$

et al. 2015). Similar to Gynura procumbens, some other plant species under the genus Gynura also exert inhibitory effect on NO production level. Gynura bicolor extract and compound 8,8'-(ethene-1,2-diyl)-dinaphtalene-1,4,5trio isolated from Gynura segetum have been shown to downregulate NO level in LPS-stimulated RAW 264.7 cells (Wu et al. 2013; Yuandani et al. 2017).

Based on the research by Byeon et al. (2012) and Shao et al. (2008), the plant polysaccharides isolated from Tripterygium wilfordii and Korean Red Ginseng possess the capacity to activate NO production in non-stimulated RAW 264.7 cells which are associated with enhanced iNOS transcription. A paradoxical effect of plant-based polysaccharides on macrophages is reported in these two studies as suppression of LPS-stimulated NO production and iNOS mRNA expression were also recorded. Thus, the inhibitory effect of Gynura procumbens extract in NO overproduction stimulated by LPS could possibly caused by the presence of polysaccharides in this plant but no detailed study has been done yet.
EFFECT OF Gynura procumbens EXTRACT ON INOS PROTEIN EXPRESSION IN RAW 264.7 CELLS

Subsequent to the significant inhibition of LPS-stimulated NO production in the previous assay, western blot was carried out by using the same extract treatment groups with LPS-stimulated RAW 264.7 macrophages. By referring to the studied pharmacological effects of the identified phytoconstituents in Gynura procumbens, the mechanism of actions in NO production inhibition by this plant extract had been focused on iNOS protein expression. As shown in Figure 3, the iNOS protein expression was significantly stimulated by LPS $(p<0.0001)$ compared to the unstimulated control group. At the transcription level, NO production by iNOS is regulated where the gene encoding iNOS is transcriptionally silent in physiological condition. However, LPS will drastically induce NO level in macrophages (Jacobs \& Ignarro 2001) via the tolllike receptor dependent signaling pathways activation (Anderson 2000). 


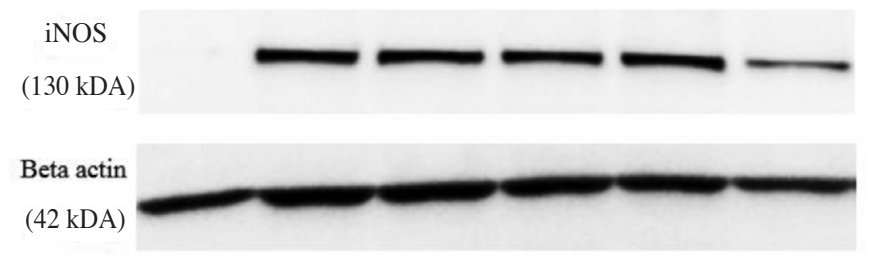

1.2

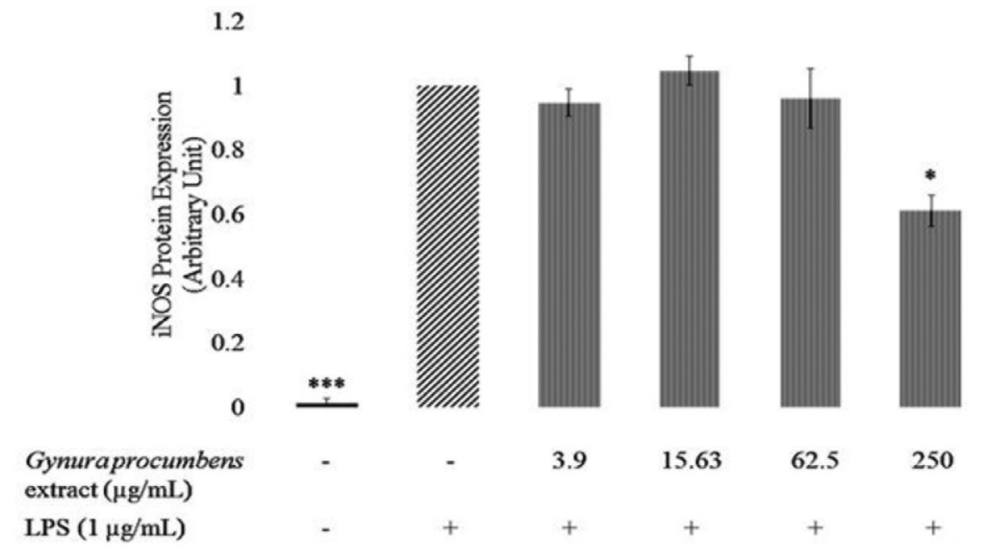

FIGURE 3. Effect of Gynura procumbens extract on inducible nitric oxide synthase (iNOS) protein expression by LPSstimulated RAW 264.7 cells. Representative image of iNOS protein expression in western blot analysis was shown above quantitative analysis bar chart. Beta actin was used as loading control. Values are mean \pm SEM of four independent experiments $(n=4)$. Significant difference compared to LPS-stimulated group $*(p<0.05) ; * * *(p<0.0001)$

With Gynura procumbens extract at 3.9, 15.63 and $62.5 \mu \mathrm{g} / \mathrm{mL}$ respectively, the iNOS protein expression showed no significant alteration. The arbitrary unit of iNOS protein expression in LPS-stimulated RAW 264.7 cells pretreated with these three extract concentrations were 0.95 $\pm 0.04,1.05 \pm 0.04$ and $0.96 \pm 0.08$. Complementary to the findings in NO production level in present study, the iNOS protein expression induced by LPS in RAW 264.7 cells was significantly downregulated $(p<0.05)$ with 250 $\mu \mathrm{g} / \mathrm{mL}$ Gynura procumbens extract pre-treatment. The LPS-stimulated iNOS protein expression was suppressed by $250 \mu \mathrm{g} / \mathrm{mL}$ Gynura procumbens extract to $0.61 \pm 0.04$ arbitrary unit. In current study, the finding of NO inhibition through iNOS protein expression suppression is supported by the pharmacological effects of Gynura procumbens phytoconstituents as reported in previous studies (Kim \& Kim 2011; Li et al. 2014; Ma et al. 2015). Based on previous research, astragalin and chlorogenic acid which are identified active compounds in Gynura procumbens (Li et al. 2015; Rosidah et al. 2008) could be the potential contributors of the inhibitory effect in LPS-stimulated NO production and iNOS protein expression (Hwang et al. 2014; Kim \& Kim 2011).

When exposed to inflammatory stimuli, macrophages secrete cytokines such as tumor necrosis factor alpha (TNF- $\alpha$ ), IL-1, IL-6, IL-8, and IL-12 which can regulate iNOS expression by activating iNOS gene promoter (Tripathi et al. 2007). Meanwhile, mitogen-activated protein kinase (MAPK) pathway activation can be initiated by LPS and TNF- $\alpha$ (Harikrishnan et al. 2018). Subsequently, the nuclear factor kappa-B (NF-KB) and activator protein-1 (AP1) which are the key pro-inflammatory transcription factors, will also be activated (Salim et al. 2016). Two NF-kB binding sites are located on iNOS gene promoter, where full induction of iNOS by LPS activation can only be achieved when both of the binding sites are bound (Aldridge et al. 2008). In macrophages, LPS-stimulated NF-kB induce iNOS expression and further enhance NO production $(\mathrm{Li}$ et al. 2002). Extract from Gynura bicolor, another plant from the genus Gynura which was mentioned previously, possesses NO inhibition by suppressing LPS-stimulated $\mathrm{NF}-\mathrm{\kappa B}$ activation and subsequently decrease the iNOS protein level in a dose-dependent manner (Wu et al. 2013). Simultaneously, the astragalin also exerts inhibitory effect on NO and iNOS via NF-KB and MAPK signaling pathway (Kim \& Kim 2011; Li et al. 2014; Ma et al. 2015).

In a study performed by Wong et al. (2015), Gynura procumbens has been demonstrated to possess inhibitory effect on TNF- $\alpha$ and IFN- $\gamma$ level in vivo. LPS is a potent inducer of TNF- $\alpha$ and IFN- $\gamma$ production in macrophages (Kraaij et al. 2014). The pro-inflammatory IFN- $\gamma$ is able to activate the Janus kinase (JAK) and Signal Transducer and Activator of Transcription (STAT) pathway, collectively known as the JAK/STAT pathway. Two other key transcription factors involved in the regulation of iNOS gene production are synthesized by the activation of the JAK/STAT pathway: The phosphorylated STAT 1 dimers and the activated interferon regulatory factor-1 (IRF1) (Salim et al. 2016). Other than the suppression of TNF- $\alpha$ and IFN- $\gamma$ levels, the modulation on MAPK, NF- $\mathrm{KB}$ and JAK/STAT signaling pathways are another potential mechanism of actions by Gynura procumbens extract in NO and iNOS suppression. Hence, it is worth to give more attention on the possible signaling pathway modulation by Gynura procumbens 
extract to get a more comprehensive understanding and deeper insight into the role of this medicinal plant in diseases involving inflammation and immunomodulation.

\section{CONCLUSION}

The results presented in this study demonstrate that Gynura procumbens ethanolic extract has a high potential to suppress NO production level and iNOS protein expression in LPS-stimulated RAW 264.7 macrophages. The findings of this study provide evidence that support the traditional use of Gynura procumbens in the treatment of inflammatory diseases. With present findings and literature reviews, further exploration on potential and benefits of Gynura procumbens extract at molecular levels along with the discovery of key chemical constituents or bioactive molecules responsible for the anti-inflammatory activities are essential.

\section{ACKNOWLEDGEMENTS}

We gratefully acknowledge the financial support by NKEA Research Grant Scheme (NRGS) from the Ministry of Agriculture (MOA) (NH1015D076), Malaysia.

\section{REFERENCES}

Akowuah, G.A., Sadikun, A. \& Mariam, A. 2002. Flavonoid identification and hypoglycaemic studies of the butanol fraction from Gynura procumbens. Pharmaceutical Biology 40(6): 405-410.

Aktan, F. 2004. iNOS-mediated nitric oxide production and its regulation. Life Sciences 75(6): 639-653.

Aldridge, C., Razzak, A., Babcock, T.A., Helton, W.S. \& Espat, N.J. 2008. Lipopolysaccharide-stimulated RAW 264.7 macrophage inducible nitric oxide synthase and nitric oxide production is decreased by an Omega-3 fatty acid lipid emulsion. The Journal of Surgical Research 149(2): 296-302.

Alexander, C. \& Rietschel,E.T. 2001. Bacterial lipopolysaccharides and innate immunity. Journal of Endotoxin Research 7(3): 167-202.

Anderson, K.V. 2000. Toll signaling pathways in the innate immune response. Current Opinion in Immunology 12(1): 13-19.

Bobryshev, Y.V., Ivanova, E.A., Chistiakov, D.A., Nikiforov, N.G. \& Orekhov, A.N. 2016. Macrophages and their role in atherosclerosis: Pathophysiology and transcriptome analysis. BioMed Research International 2016: 9582430.

Byeon, S.E., Lee, J., Kim, J.H., Yang, W.S., Kwak, Y.S., Kim, S.Y., Choung, E.S., Rhee, M.H. \& Cho, J.Y. 2012. Molecular mechanism of macrophage activation by red ginseng acidic polysaccharide from Korean red ginseng. Mediators of Inflammation 2012: 732860.

Dianita, R., Jantan, I., Amran, A.Z. \& Jalil, J. 2015. Protective effects of Labisia pumila var. alata on biochemical and histopathological alterations of cardiac muscle cells in isoproterenol-induced myocardial infarction rats. Molecules (20): 4746-4763.

Fujiwara, N. \& Kobayashi, K. 2005. Macrophages in inflammation. Current Drug Targets: Inflammation and Allergy 4(3): 281286.
Hämäläinen, M., Nieminen, R., Vuorela, P., Heinonen, M. \& Moilanen, E. 2007. Anti-inflammatory effects of flavonoids: Genistein, kaempferol, quercetin, and daidzein inhibit STAT-1 and NF-kappaB activations, whereas flavone, isorhamnetin, naringenin, and pelargonidin inhibit only NFkappaB activation along with their inhibitory effect on iNOS expression and NO production in activated macrophages. Mediators of Inflammation 2007: 45673.

Harikrishnan, H., Jantan, I., Haque, M.A. \& Kumolosasi, E. 2018. Anti-inflammatory effects of Phyllanthus amarus Schum. \& Thonn. through inhibition of NF-kB, MAPK, and PI3K-Akt signaling pathways in LPS-induced human macrophages. BMC Complementary and Alternative Medicine 18(1): 224.

Hwang, S.J., Kim, Y.W., Park, Y., Lee, H.J. \& Kim, K.W. 2014. Anti-inflammatory effects of chlorogenic acid in lipopolysaccharide-stimulated RAW 264.7 cells. Inflammation Research 63(1): 81-90.

Iskander, M.N., Song, Y., Coupar, I.M. \& Jiratchariyakul, W. 2002. Anti-inflammatory screening of the medicinal plant Gynura procumbens. Plant Foods for Human Nutrition 57(3-4): 233-244.

Jacobs, A.T. \& Ignarro, L.J. 2001. Lipopolysaccharide-induced expression of interferon- $\beta$ mediates the timing of inducible nitric-oxide synthase induction in RAW 264.7 macrophages. The Journal of Biological Chemistry 276(51): 47950-47957.

Joo, T., Sowndhararajan, K., Hong, S., Lee, J., Park, S.Y., Kim, S. \& Jhoo, J.W. 2014. Inhibition of nitric oxide production in LPS-stimulated RAW 264.7 cells by stem bark of Ulmus pumila L. Saudi Journal of Biological Sciences 21(5): 427 435.

Kaewseejan, N., Puangpronp, D. \& Nakornriab, M. 2012. Evaluation of phytochemical composition and antibacterial property of Gynura procumbens extract. Asian Journal of Plant Sciences 11(2): 77-82.

Kamaruzaman, K.A. \& Noor, M.M. 2017. Gynura procumbens leaf improves blood glucose level, restores fertility and libido of diabetic-induced male rats. Sains Malaysiana 46(9): 1471-1477.

Kim, H.J., Tsoyi, K., Heo, J.M., Kang, Y.J., Park, M.K., Lee, Y.S., Lee, J.H., Seo, H.G., Yun-Choi, H.S. \& Chang, K.C. 2007. Regulation of lipopolysaccharide-induced inducible nitricoxide synthase expression through the nuclear factor-kappaB pathway and interferon-beta/tyrosine kinase $2 /$ Janus tyrosine kinase 2-signal transducer and activator of transcription-1 signaling cascad. The Journal of Pharmacology and Experimental Therapeutics 320(2): 782-789.

Kim, J., Lee, C.W., Kim, E.K., Lee, S.J., Park, N.H., Kim, H.S., Kim, H.K., Char, K., Jang, Y.P. \& Kime, J.W. 2011. Inhibition effect of Gynura procumbens extract on UV-B-induced matrix-metalloproteinase expression in human dermal fibroblasts. Journal of Ethnopharmacology 137(1): 427-433.

Kim, M.S. \& Kim, S.H. 2011. Inhibitory effect of astragalin on expression of lipopolysaccharide-induced inflammatory mediators through NF- $\mathrm{KB}$ in macrophages. Archives of Pharmacal Research 34(12): 2101-2107.

Kopincová, J., Púzserová, A. \& Bernátová, I. 2012. L-NAME in the cardiovascular system - Nitric oxide synthase activator? Pharmacological Reports 64(3): 511-520.

Korhonen, R., Lahti, A., Kankaanranta, H. \& Moilanen, E. 2005. Nitric oxide production and signaling in inflammation. Current Drug Targets: Inflammation and Allergy 4(4): 471479.

Kraaij, M.D., Vereyken, E.J.F., Leenen, P.J.M., van den Bosch, T.P.P., Rezaee, F., Betjes, M.G.H., Baan, C.C. \& Rowshani, 
A.T. 2014. Human monocytes produce interferon-gamma upon stimulation with LPS. Cytokine 67(1): 7-12.

Li, F., Wang, W., Cao, Y., Liang, D., Zhang, W., Zhang, Z., Jiang, H., Guo, M. \& Zhang, N. 2014. Inhibitory effects of astragalin on lipopolysaccharide-induced inflammatory response in mouse mammary epithelial cells. Journal of Surgical Research 192(2): 573-581.

Li, X.J., Mu, Y.M., Li, T.T., Yang, Y.L., Zhang, M.T., Li, Y.S., Zhang, W.K., He-Bin, T. \& Shang, H.C. 2015. Gynura procumbens reverses acute and chronic ethanol-induced liver steatosis through MAPK/SREBP-1c-dependent and -independent pathways. Journal of Agricultural and Food Chemistry 63(38): 8460-8471.

Li, Y.H., Yan, Z.Q., Brauner, A. \& Tullus, K. 2002. Activation of macrophage nuclear factor- $\mathrm{\kappa B}$ and induct ion of inducible nitric oxide synthase by LPS. Respiratory Research 3(1): 23.

Łuszczki, J.J., Jaskólska, A., Dworzański, W. \& Zółkowska, D. 2011. 7-nitroindazole, but not NG-nitro-L-arginine, enhances the anticonvulsant activity of pregabalin in the mouse maximal electroshock-induced seizure model. Pharmacological Reports: PR 63(1): 169-175.

Ma, Z., Piao, T., Wang, Y. \& Liu, J. 2015. Astragalin inhibits IL-1 $\beta$-induced inflammatory mediators production in human osteoarthritis chondrocyte by inhibiting NF- $\mathrm{kB}$ and MAPK activation. International Immunopharmacology 25(1): 83-87.

Mustafizur Rahman, A.F.M. \& Al Asad, M.S. 2013. Chemical and biological investigations of the leaves of Gynura procumbens. International Journal of Biosciences 3(4): 36-43.

Nicholas, C., Batra, S., Vargo, M.A., Voss, O.H., Gavrilin, M.A., Wewers, M.D., Guttridge, D.C., Grotewold, E. \& Doseff, A.I. 2007. Apigenin blocks lipopolysaccharide-induced lethality in vivo and proinflammatory cytokines expression by inactivating NF-kappa B through the suppression of p65 phosphorylation. Journal of Immunology 179(10): 71217127.

Rosidah, Y., Sadikun, A.M. \& Asmawi, M. 2008. Antioxidant potential of Gynura procumbens. Pharmaceutical Biology 46(9): 616-625.

Salim, T., Sershen, C.L. \& May, E.E. 2016. Investigating the role of TNF- $\alpha$ and IFN- $\gamma$ activation on the dynamics of iNOS gene expression in LPS stimulated macrophages. Plos ONE 11(6): e0153289.

Shao, D., Dunlop, W.D., Lui, E.M.K. \& Bernards, M.A. 2008. Immunostimulatory and anti-inflammatory polysaccharides from Tripterygium wilfordii: Comparison with organic extracts. Pharmaceutical Biology 46(1-2): 8-15.

Shi, Q., Cao, J., Fang, L., Zhao, H., Liu, Z., Ran, J., Zheng, X., Li X., Zhou, Y., Di, Ge., Zhang, H., Wang, L., Rana, Y. \& Fua, J. 2014. Geniposide suppresses LPS-induced nitric oxide, PGE2 and inflammatory cytokine by downregulating NF$\kappa \mathrm{B}, \mathrm{MAPK}$ and AP-1 signaling pathways in macrophages. International Immunopharmacology 20(2): 298-306.

Soufli, I., Toumi, R., Rafa, H. \& Touil-Boukoffa, C. 2016. Overview of cytokines and nitric oxide involvement in immuno-pathogenesis of inflammatory bowel diseases. World Journal of Gastrointestinal Pharmacology and Therapeutics 7(3): 353-360.

Sunarwidhi, A.L., Sudarsono, S. \& Nugroho, A.E. 2014. Hypoglycemic effect of combination of Azadirachta indica A. Juss. and Gynura procumbens (Lour.) Merr. ethanolic extracts standardized by rutin and quercetin in alloxaninduced hyperglycemic rats. Advanced Pharmaceutical Bulletin 4(2): 613-618.
Tabas, I. \& Bornfeldt, K.E. 2016. Macrophage phenotype and function in different stages of atherosclerosis. Circulation Research 118(4): 653-667.

Tripathi, P., Tripathi, P., Kashyap, L. \& Singh, V. 2007. The role of nitric oxide in inflammatory reactions. FEMS Immunology \& Medical Microbiology 51(3): 443-452.

Wong, S.K., Lee, M.S.J., Sudi, S., Hassan, R.M., Lee, P.C., Embi, N. \& Sidek, H. 2015. Anti-malarial and anti-inflammatory effects of Gynura procumbens are mediated by kaempferol

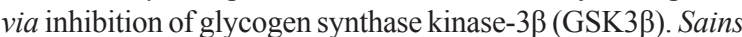
Malaysiana 44(10): 1489-1500.

Wu, C.C., Lii, C.K., Liu, K.L., Chen, P.Y. \& Hsieh, S.L. 2013. Antiinflammatory activity of gynura bicolor (紅鳳菜 Hóng Fèng Cài) ether extract through inhibits nuclear factor Kappa B activation. Journal of Traditional and Complementary Medicine 3(1): 48-52.

Yuandani, Jantan, I. \& Husain, K. 2017. 4,5,4'-Trihydroxychalcone, 8,8'-(ethene-1,2-diyl)-dinaphtalene-1,4,5-triol and rutin from Gynura segetum inhibit phagocytosis, lymphocyte proliferation, cytokine release and nitric oxide production from phagocytic cells. BMC Complementary and Alternative Medicine 17(1): 211

Tan Jiah Ning, Syaratul Dalina Yusoff, Fhataheya Buang, Tan Ze Song, Ameerah Budiono, Endang Kumolosasi, Norazrina Azmi \& Norsyahida Mohd Fauzi*

Drug and Herbal Research Centre

Faculty of Pharmacy

Universiti Kebangsaan Malaysia

Jalan Raja Muda Abdul Aziz

50300 Kuala Lumpur

Malaysia

Zakiah Jubri

Department of Biochemistry

Faculty of Medicine

Universiti Kebangsaan Malaysia

Jalan Yaacob Latiff, Bandar Tun Razak

56000 Cheras, Kuala Lumpur, Federal Territory

Malaysia

Ibrahim Jantan

School of Pharmacy

Taylor's University, Lakeside Campus

47500 Subang Jaya, Selangor Darul Ehsan

Malaysia

Roza Dianita

School of Pharmaceutical Sciences

Universiti Sains Malaysia

11800 USM Pulau Pinang

Malaysia

*Corresponding author; email: drnorsyahida@ukm.edu.my

Received: 14 September 2018

Accepted: 31 May 2019 